\title{
THE INFLUENCE OF LADLE SHROUD MISALIGNMENT ON STEEL FLOW IN THREE STRAND T-SHAPE TUNDISH
}

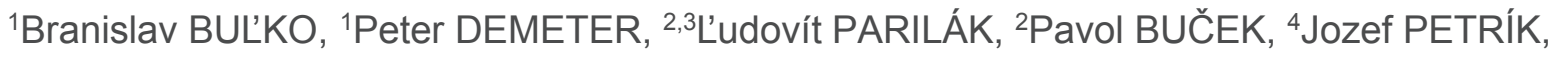 \\ ${ }^{4}$ Peter BLAŠKO, ${ }^{1}$ Dana BARICOVÁ, ${ }^{2}$ Vladimír CHOMIČ, ${ }^{5}$ Pavol VESELOVSKÝ \\ ${ }^{1}$ Technical University of Košice, Faculty of Materials, Metallurgy and Recycling, Institute of Metallurgy, \\ Košice, Slovak Republic, EU, branislav.bulko@tuke.sk \\ 2ŽP VVC s.r.o., Podbrezová, Slovak Republic, EU, parilak@zelpo.sk \\ ${ }^{3}$ Technical University of Košice, Faculty of Manufacturing Technologies, Prešov, Slovak Republic, EU, \\ parilak@zelpo.sk \\ ${ }^{4}$ Technical University of Košice, Faculty of Materials, Metallurgy and Recycling, Institute of Materials and \\ Quality Engineering, Košice, Slovak Republic, EU, jozef.petrik@tuke.sk \\ ${ }^{5}$ Železiarne Podbrezová a.s., Podbrezová, Slovak Republic, EU, veselovsky.pavol@zelpo.sk
}

https://doi.org/10.37904/metal.2019.679

\begin{abstract}
The residence time for individual tundish configuration is one of the most important factors of the tundish metallurgy. In the T-type tundishes, it is difficult to set a tundish furniture in order to obtain similar residence time for every strand. The tundish furniture is obviously designed for correct set ladle shroud position and angle. In this paper is quantified the ladle shroud deviation angle from vertical axis on residence time of three strand tundish of Železiarne Podbrezová, a.s. (ŽP). using water model in scale 1:2. In the continuous casting machine in ŽP, the manual ladle shroud mounting on ladle is used. Generally, the misalignment of the shroud has a negative effect on the flow of the steel in the tundish. This fact may negatively affect the cleanliness of the cast steel but also wearing of the exposed places of the tundish lining. The results are also evaluated by using sophisticated statistical methods.
\end{abstract}

Keywords: Steel, continuous casting, tundish, water model, flow simulation, ladle shroud

\section{INTRODUCTION}

Increasing demands on steel quality, production and casting performance promote continuous innovation efforts in the steel industry. For example, mathematical and physical modelling of continuous casting of steel including the steel flow in a tundish is now a vital part of the overall optimization process. Within this framework, the SimConT laboratory was built as a joint effort of the ZP Research and Development Centre (ZP VVC) in Podbrezová and the Faculty of Materials, Metallurgy and Recycling of the Technical University of Košice. The laboratory focuses on basic and applied research in physical modelling and optimization of liquid steel flow in a three-strand, T-type tundish used in the Železiarne Podbrezová steel plant at Podbrezová, Slovakia. A topclass, 1:2-scale physical model of the tundish is at the heart of the SimConT laboratory. The model uses water to simulate the liquid steel flow in both steady and transient casting conditions and is fully controlled by the Simatic ${ }^{\circledR}$ control system.

During the projecting of the water model of the tundish [1], the question of the precise position of the ladle shroud against the impact pad was solved. Since this is one of the key parameters influencing the flow of steel in tundish, during layoff the cold tundish was placed in continuous casting machine and the empty ladle with new ladle shroud was placed on the ladle turret Figure 1, Figure 2, Figure 3 [2-6]. On this system were performed measurements of real position of ladle shroud. 


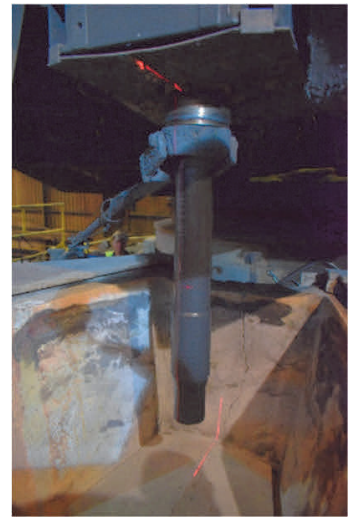

Figure 1 The measurement of precise of ladle shroud setup

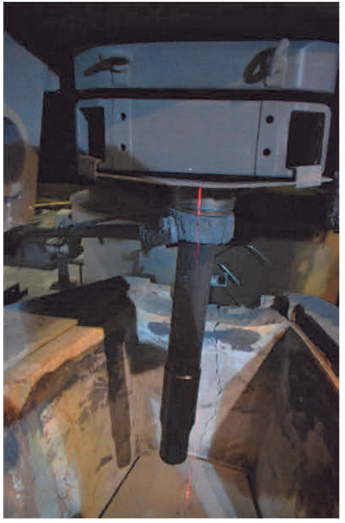

Figure 2 The possibility of ladle shroud deviation to the side wall of tundish

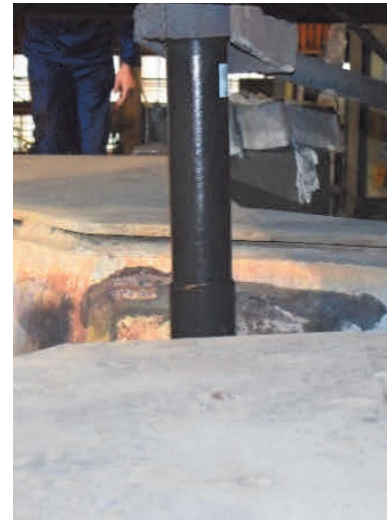

Figure 3 The example of ladle shroud deviation directed to the rear wall of the tundish

After inspection and consultation of this problem with operators, the main factors influencing the ladle shroud precision mounting were resumed:

a) The ladle shroud can be mounted in various angles by operator using mechanical arm. The precise of ladle shroud mounting can increase only from his angle of view. The example of real mounting of ladle shroud is in Figure 4. This can affect not only the impact point of steel on the impact pad, but also the angle of an impact.
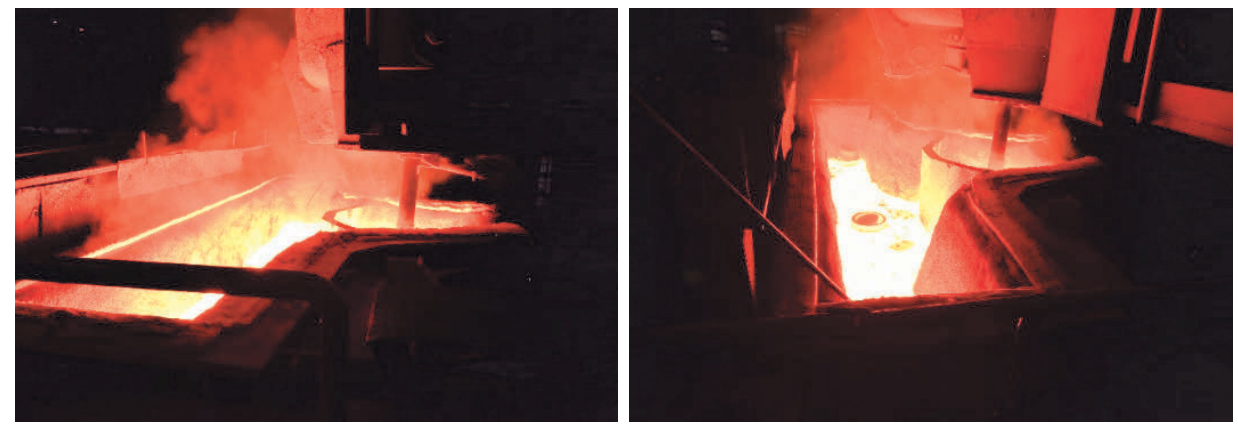

Figure 4 The examples of ladle shroud mounting during casting

b) The ladle turret drive has not a position switch. Stopping of the ladle turret is performed manually using marks.

c) The position of impact pad in the tundish is not exactly specified. Impact pad can be placed $5-7 \mathrm{~cm}$ against anterodorsally axis.

\section{SIMULATION OF LADLE SHROUD MISALIGNEMENT}

Based on the above findings, extensive number of simulations have been performed to approximate this phenomenon for a ladle shroud misaligned by $5 \mathrm{~cm}$ relative to a vertical axis along a circle on 8 points. This misalignment corresponds to a $10 \mathrm{~cm}$ on the real ladle shroud. Individual configurations are identified by the letters A - H (Figure 5). The parameters of simulation of casting are in Table 1. The ideal ladle shroud setting $\left(0^{\circ}\right.$ deviation $)$ is represented by configuration "O".

The main monitored parameter, in addition to the visual assessment of steel flow, was the tundish residence time, describing the residence time of the steel in the tundish in steady state, represented by the C-curve $[7,8]$. 


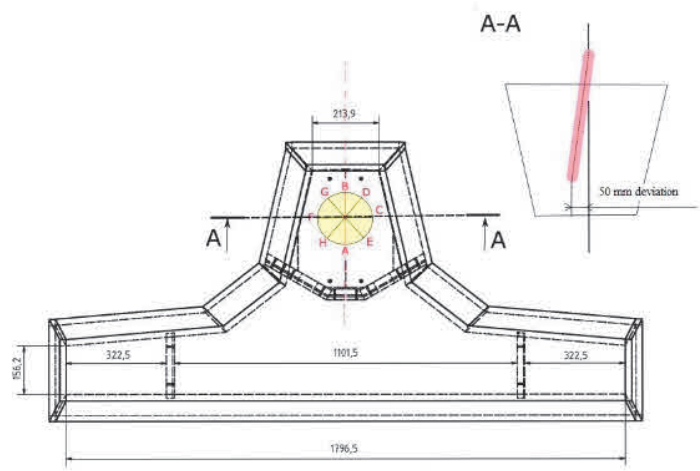

Figure 5 The points of ladle shroud deviation for simulations

Table 1 The parameters of simulation of ladle shroud deviation

\begin{tabular}{|c|c|}
\hline Regime & Steady State \\
\hline Water level in tundish & $320 \mathrm{~mm}$ \\
\hline Water flow, each strand & $81 . \mathrm{min}^{-1}$ \\
\hline Volumetric flow rate from ladle into tundish & $24 \mathrm{I} \cdot \mathrm{min}^{-1}$ \\
\hline Number of repetition of measurements & 3 \\
\hline Amount of used tracer & $150 \mathrm{ml}$ \\
\hline
\end{tabular}

Measured values of residence time are in Table 2.

Table 2 Measured values of minimal and maximal residence time for each ladle shroud deviation

\begin{tabular}{|c|c|c|c|c|c|c|}
\hline Configuration & $\begin{array}{l}\text { 1. strand } \\
T_{\min }\end{array}$ & $\begin{array}{l}\text { 1. strand } \\
T_{\max }\end{array}$ & $\begin{array}{l}\text { 2. strand } \\
T_{\min }\end{array}$ & $\begin{array}{l}\text { 2. strand } \\
T_{\max }\end{array}$ & $\begin{array}{l}\text { 3. strand } \\
T_{\min }\end{array}$ & $\begin{array}{l}\text { 3. strand } \\
T_{\max }\end{array}$ \\
\hline A & 63.7 & 230.7 & 24 & 77 & 65.5 & 188.3 \\
\hline B & 68.7 & 209.17 & 41.2 & 85 & 73.8 & 197 \\
\hline C & 76.3 & 224.8 & 26.7 & 121 & 73.5 & 205.7 \\
\hline D & 61.3 & 182.3 & 29.7 & 167.3 & 72.7 & 189 \\
\hline E & 68 & 237.3 & 25.5 & 105.5 & 67.3 & 253.25 \\
\hline $\mathbf{F}$ & 58.8 & 225.8 & 26.5 & 93.8 & 74.7 & 228.8 \\
\hline G & 54.8 & 180.8 & 33.8 & 107.5 & 64 & 182.5 \\
\hline $\mathrm{H}$ & 62 & 234.7 & 25.5 & 109 & 57.5 & 188 \\
\hline 0 & 66 & 213.8 & 33.2 & 133 & 68.2 & 207.5 \\
\hline
\end{tabular}

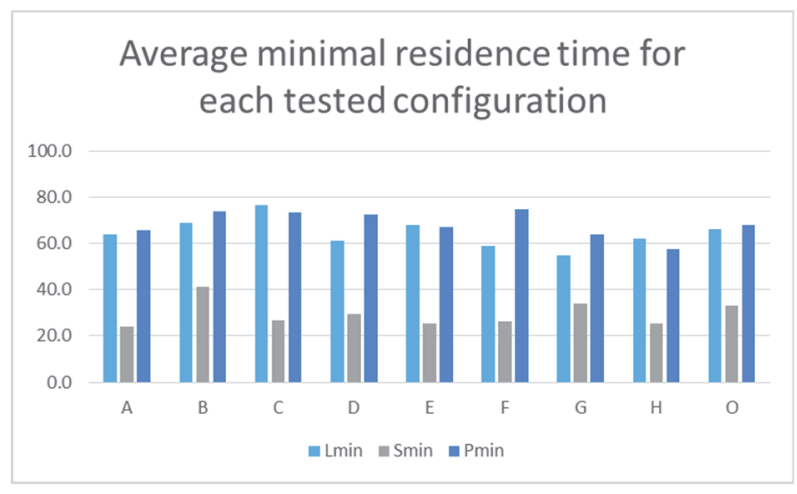

Figure 6 Minimal residence time for tested configuration
Average maximal residence time for each tested configuration

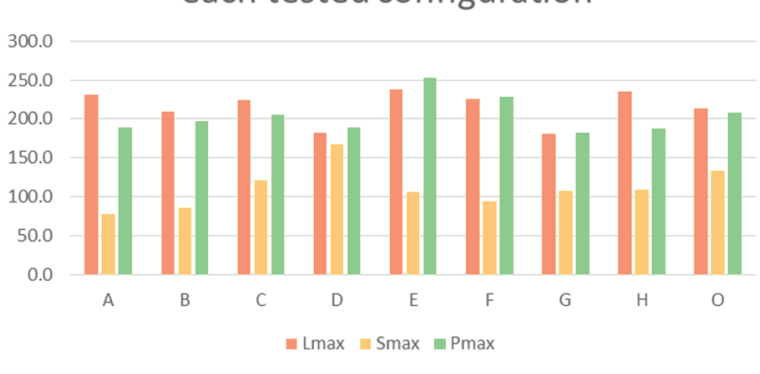

Figure 7 Maximal residence time for tested configuration 
A clear summary of the residence time achieved on each strand is shown in Figure 6 and Figure 7. Each configuration was tested 3 times and the average value is always presented in the graphs.

Mirror configurations (E - H. G - D. F - C) were compared to verify the accuracy of the measurements. The graphs show a relatively high match for mirror configuration measurements. The inaccuracies could be due to turbulence and deviation of the angle setting of the ladle shroud.

\section{STATISTICAL EVALUATION OF THE LADLE SHROUD MISALIGNMENT ON THE RESIDENCE TIME}

The measured data were statistically evaluated by metrology experts at the Institute of Materials Engineering and Quality. FMMR. The individual strands are designated: strand No. 1 as L (left), strand No. 2 as C (central) and strand No. 3 as R (right) in the following text.

Table 3 descriptive statistics

\begin{tabular}{|c|c|c|c|c|c|c|}
\hline & \multicolumn{3}{|c}{ Minimal residence time } & \multicolumn{3}{c|}{ Maximal residence time } \\
\hline strand & $\mathrm{L}\left(\boldsymbol{T}_{\min }\right)$ & $\mathrm{C}\left(\boldsymbol{T}_{\min }\right)$ & $\mathrm{R}\left(\boldsymbol{T}_{\min }\right)$ & $\mathrm{L}\left(\boldsymbol{T}_{\max }\right)$ & $\mathrm{C}\left(\boldsymbol{T}_{\max }\right)$ & $\mathrm{R}\left(\boldsymbol{T}_{\max }\right)$ \\
\hline mean value & 64.208 & 29.104 & 68.615 & 215.698 & 108.271 & 204.073 \\
\hline standard deviation & 9.36 & 6.761 & 7.923 & 27.566 & 36.274 & 33.788 \\
\hline normality 1 (p-value) & 0.383 & 0.352 & 0.662 & 0.297 & 0.538 & 0.57 \\
\hline normality 2 (p-value) & 0.172 & 0.047 & 0.857 & 0.112 & 0.816 & 0.644 \\
\hline
\end{tabular}

Outliers were determined by the Grubbs test at a significance level of $\alpha=0.05$ using the Graphpad software. The presence of outliers would signal that the process is out of statistical control and is affected by assignable (not common) causes. The data normality has been determined and confirmed by software QuantumXL using (1) module "Design of Experiment (DoE)" or (2) Anderson-Darling test. If the p-value is greater than the significance level $(\alpha=0.05)$ the file of measured values has a normal distribution and parametric tests can be used for the analysis $[9,10,11]$. The descriptive statistics of the considered files (mean residence time, their standard deviation, the number of outliers, and the p-value of normality tests) are shown in Table 3.

Figures 8 and 9 show diagrams illustrating the relationship between the misalignment of the ladle shroud and the minimum (Figure 8) and maximum (Figure 9) residence time.

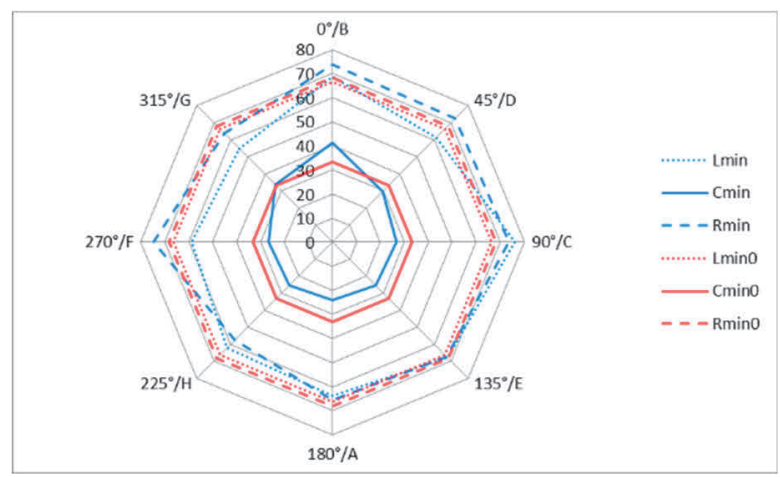

Figure 8 The minimal residence time

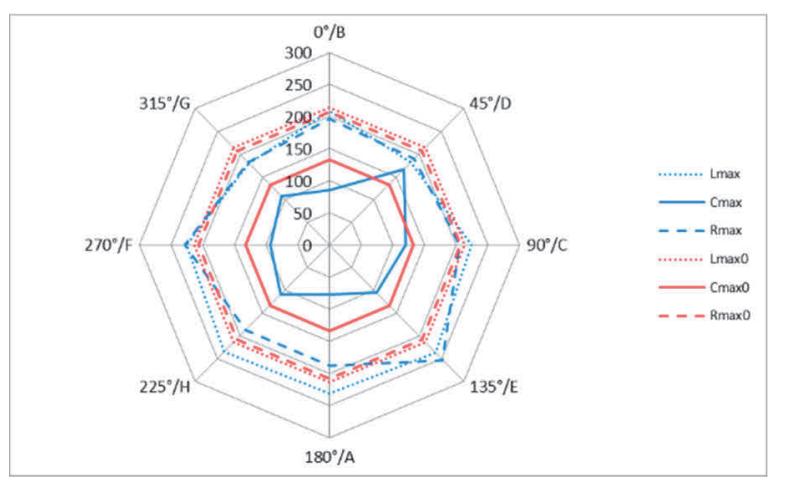

Figure 9 Maximal residence time

The situation for minimum residence time for correctly set ladle shroud is shown in Figure 8. The residence time $L_{\min 0}$ for the left, $\mathrm{C}_{\min 0}$ for the central and $\mathrm{R}_{\min 0}$ for the right strand are indicated red. Residence time for misaligned shroud are $L_{\min }$ for the left, $\mathrm{C}_{\min }$ for the central and $\mathrm{R}_{\min }$ for the right strand, marked in blue. The greatest disagreement between the minimum residence times on the individual strands is at the angle $270^{\circ}$ 
(position $\mathrm{F}$ ), the maximum agreement is at an angle of $0^{\circ}$ (position $\mathrm{B}$ ). There is a certain difference between the residence time of the right and the left strands, but the difference between them and the central strand declined in this case.

The situation for maximum residence time for correctly set ladle shroud is shown in Figure 9. The residence time $L_{\max 0}$ for the left, $C_{\max 0}$ for the central and $R_{\max 0}$ for the right strand are indicated red. Residence time for

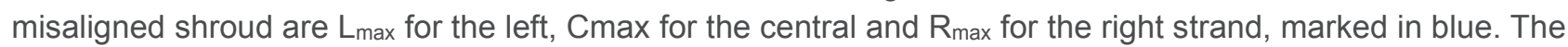
greatest disagreement between the residence time at the individual strands is $180^{\circ}(\mathrm{A}), 225^{\circ}(\mathrm{H})$, and $135^{\circ}$ $(E)$, the maximum agreement is at the angle of $45^{\circ}(D)$.

The statistical significance of the rotation of the misaligned shroud (factor No. 1) and the strand (all three, without resolution, factor No. 2) on the residence time was evaluated using two-way ANOVA (analysis of the variability) method with replication (three repetitions for each shroud/strand configuration). If calculated the $p$ value is greater than the considered significance level $(\alpha=0.05)$, the factor is not statistically significant. As shown in Table 4, both factors - the angle of rotation and the strand - have a statistically significant effect on the minimum and maximum residence time. At the same time, their mutual influence (interaction) is also statistically significant [11].

Table 4 p-values for two-way ANOVA

\begin{tabular}{|c|c|c|}
\hline & Minimal residence time & Maximal residence time \\
\hline strand (L. C. R) & $2.13 \mathrm{E}-26$ & $3.4 \mathrm{E}-19$ \\
\hline rotation of the shroud & 0.002626 & 0.043277 \\
\hline interaction & 0.030394 & 0.003468 \\
\hline
\end{tabular}

The influence of the rotation angle of the deflected shroud on the residence time in the individual strands was analysed using a single-way ANOVA. As shown in Table 5, the residence times on the individual strands are not evenly affected. The left strand is not significantly affected at the minimum residence time and both central and right strands are not significantly affected at the maximum residence time. The value $\alpha(\%)$ is the percentage of variability resulting from the observed factor.

Table 5 p-values for one-way ANOVA

\begin{tabular}{|c|c|c|c|c|c|c|}
\hline & \multicolumn{3}{|c}{ Minimal residence time } & \multicolumn{3}{c|}{ Maximal residence time } \\
\hline strand & $\mathrm{L}$ & $\mathrm{C}$ & $\mathrm{R}$ & $\mathrm{L}$ & $\mathrm{C}$ & $\mathrm{R}$ \\
\hline p-value & 0.122693 & 0.005894 & 0.04746 & 0.122693 & 0.005894 & 0.092037 \\
\hline $\boldsymbol{\alpha}(\%)$ & 46.4 & 66.5 & 54,1 & 46.4 & 66.5 & 48,9 \\
\hline
\end{tabular}

\section{DISCUSSION}

a) The ladle shroud manipulator allows the tube to be mounted at any angle - signalling the correct position, or full automation of the ladle shroud mounting on the ladle (it would be appropriate to associate with the slag penetration detection system).

b) The ladle turret rotation control allows to stop in any position, control system use only with marks on ladle turret - high tolerance - installation of end sensors on the ladle turret.

c) The seat on the ladle in the ladle turret does not have a precisely defined place and the crane puts it in with a certain tolerance - welding the pins on the ladle and ladle turret, securing the exact position of the ladle in the ladle turret.

d) Impact pad is inserted into tundish manually with relatively large tolerance - to ensure constant position of impact pad in tundish. 
None of the action themselves will have a significant impact on ensuring constant conditions for the flow of steel in the tundish, these actions must all be resolved.

\section{CONCLUSIONS}

For all configurations, including the correct ladle shroud setting (configuration 0), the residence time of the centre strand is always the shortest. The misalignment of the ladle shroud results in a shortening of the minimum residence time in the centre strand, except configuration $B$ (the ladle shroud towards to the back wall of the tundish). The deviation of the ladle shroud to the back wall of the tundish results in the prolongation of the residence time on all strands - although this is a positive effect in terms of steel flow, this cannot be considered as desired phenomenon. Negatives may be caused, for example, by increased wear of the refractory lining of the tundish. The misalignment of the ladle shroud generally has a negative effect on the flow of steel in the tundish, which can negatively affect the cleanliness of the cast steel, but also to a more pronounced wear of exposed tundish work lining areas [12-16].

\section{ACKNOWLEDGEMENTS}

This paper was prepared under grant project No.1/0868/17 with financial support of VEGA MŠ SR and SAV.

\section{REFERENCES}

[1] DEMETER, P., BUL'KO, B. Laboratory of Simulation of Flow Processes. [viewed 2019-02-22]. Available from: https://ohaz.umet.fmmr.tuke.sk/lspp/index.html.

[2] MAZUMDAR, D., YAMANOGLU, G., SHANKARNARAYANAN, R., GUTHRIE, Ril. Similarity Considerations in the Physical Modelling of Steel Making Tundish Systems, Steel Research. 1995. vol. 66. no. 1. pp. 14-19.

[3] SAHAI, Y., AHUJA, R. Fluid Flow and Mixing of Melt in Steelmaking Tundishes, Ironmaking \& Steelmaking. 1986. vol. 13. no. 5. pp. 241-247.

[4] KORIA, Sc., SINGH, S. Physical modelling of the effects of the flow modifier on the dynamics of molten steel flowing In a tundish, ISIJ International. 1994. vol. 34. no. 10. pp. 784-793.

[5] MACIOL, P., GAWAD, J., PODORSKA, D. Arrangement of flow modification devices in continuous casting tundish based on multicriterion optimization, Archives of Metallurgy and Materials, vol. 52, no. 1, pp. 105112, 2007.

[6] BUL'KO, B., KIJAC, J., DEMETER, P., DEMETER, J. Influence of misalignment ladle shroud on tundish residence time. In: Acta Metallurgica Slovaca. 2011. vol. 17. no. 1. pp. 51-57. ISSN 1338-1156 [online]. [Viewed 2014-08-22]. Available from: http://www.ams.tuke.sk/data/ams online/2011/number1/mag08/mag08.pdf

[7] MICHALEK, K. Využití fyzikálního a numerického modelování pro optimalizaci metalurgických procesů. Vysoká škola báňská - Technická univerzita Ostrava, 2001. ISBN 80-7078-861-5 (in Czech).

[8] SOCHA, L., BAZAN. J., GRYC. K., MACHOVCAK. P., MORAVKA. J., STYRNAL. P. Evaluation of fluxing agents effect on desulphurization in secondary metallurgy under plant conditions, Metalurgija. 2013. vol. 52. no. 4. pp. 485-488.

[9] CHAJDIAK, J. Štatistika v exceli. Bratislava, Statis 2002, ISBN 80-85659-27-1 (in Slovak).

[10] PALENČAR, R. RUIZ, J. M., JANIGA, I., HORNÍKOVÁ, A. Štatistické metódy v metrologických a skúšobných laboratóriách. Bratislava, Grafické štúdio Ing. Peter Juriga, 2001, ISBN 80-968449-3-8 a MSA: 113-98, 117-98 and 116-98. (in Slovak).

[11] CHAJDIAK, J. Štatistika jednoducho, Bratislava: Statis, 2013, pp. 344. ISBN 978-80-85659-60-3 (in Slovak).

[12] MICHALEK, K., CAMEK, L., GRYC. K., TKADLECKOVA, M., HUCZALA, T., TROSZOK, V. Desulphurization of the high-alloy and middle-alloy steels under the conditions of an eaf by means of synthetic slag based on $\mathrm{CaO}$ Al2O3. Materiali in tehnologije. 2012. vol. 46. no. 3. pp. 297-303. 
[13] PRIBULOVÁ, A. Influence of Blowing of Argon on the Cleanness of Steel, Archives of foundry engineering. 2012. vol. 12. no. 3. pp. 91-94.

[14] PRIBULOVÁ, A., BABIC, J., BARICOVÁ, D. Influence of hadfield's steel chemical composition on its mechanical properties. Chemické listy. vol. 105. pp. 430-432. 2011.

[15] KALISZDAK, D., ŻAK, P.L., TOKARSKI, T., WZOREK, Ł., SUCHY, J. S., KICZOR, M., CIEŚLAK, W. Computer Simulation of the Formation of Non-Metallic Precipitates During a Continuous Casting of Steel. Archives of Metallurgy and materials. 2016. vol. 61. no. 1. pp. 335-340. https://doi.org/10.1515/amm-2016-0062.

[16] RAIC, KARLO, T. Simplification of laminar boundary layer equations, Metallurgical \& Materials Engineering. 2018. vol. 24. no. 2. pp. 93-102. 